\title{
TRANSFER IN THIRD LANGUAGE PHONOLOGY: \\ DOES L3 TYPOLOGICAL PROXIMITY PLAY A ROLE? \\ Dámaris Mayans \\ University of Florida
}

\section{INTRODUCTION}

7 he study of multilingual acquisition in adulthood provides a valuable understanding of how previous linguistic knowl-

edge operates in the acquisition of a new language (FLYNN
et al.: 2004). As mentioned in Cabrelli Amaro \& Rothman (2010), unlike the previous assumption that third language acquisition was another case of adult acquisition, acquiring a third language is a unique process since the participants have two already-acquired languages. By investigating L3 acquisition we can determine if the native language (in the case of sequential acquisition of different L3) is the only source of interference in the non-native languages, if the speaker resorts to using the later acquired language, or in the case of bilinguals (with stable grammars), if they resort to both linguistic repertoires at their disposal in the acquisition of their L3.

Previous research in L3 acquisition has mainly focused on morpho-syntax (FLYNN et al:: 2004, KELVIN: 1995, ROTHMAN: 2011) or lexical transfer (ECKE \& HALL: 2000, BAYONA: 2010 among others.). The field of L3 phonology has begun to experience a greater presence in international conferences and workshops, and journals have dedicated special issues to this area (the Journal of Multilingualism-February: 2010). However, it is still an understudied domain.

There have been few proposals for determining factors in third language transference. Such theories include the L1 Transfer Hypothesis, the Cumulative Enhanced Model (CEM) (FLYNN et al:: 2004); the L2 status factor (BARDEL \& FALK: 2007) and the Typological Primacy Model (ROTHMAN: 2010). These models provide different hypothesis of language transfer but Typological Primacy Model (TPM) poses that proximity in actual or perceived linguistic proximity between one of the previously acquired languages and the L3 is one of the most salient 
variables to predict transfer. We will discuss results taking into account this model and other transfer models (discussed below).

Since previous literature on L3 transference mainly focus on syntactic properties of a language, the question that arises is whether these models of transference account for phonological transfer in L3 acquisition. The purpose of this study is to observe early bilingual speakers' patterns of phonological transfer of laterals, specifically clear and dark $/ \uparrow /$, into Catalan.

\section{CATALAN DARK LATERAL}

There is considerable research (articulatory and acoustic) that provides details about the differing characteristics of clear and dark laterals. In Spanish, the only segment that exists in the phonological repertoire is clear $/ 1 /$. In English we find $/ 1 /$ and $/ t /$ that is realized post vocalically (HUALDE: 2005), and in Catalan, dark $/ \uparrow /$ appears in all contexts (SOLÀ, RigAU \& Oliver: 2002). Both segments share the feature coronal, that is, the tip of the tongue articulates with the alveolar ridge. However, dark laterals have a secondary articulation in which the dorsum of the tongue approximates the velar region. Acoustically, in the production of dark $/ \mathrm{t} /$ the interaction of the dorsum with the velar region produces a lowering of the second formant (F2) and a raising of the first formant (F1) in comparison with the clear /1/ (RECASENS: 2004). However, there is variation in the degree of darkness or velarization. In American English and Eastern Catalan, dark $/ \mathrm{t} /$ seems to be darker in syllable final position with lower F2 and higher F1 than in syllable onset position. Also, subjacent vowels affect the production of the dark $/ 1 /$. This lateral is produced with less backing and lowering of the dorsum in contact with high front vowels such as /i/ while the clear lateral is less clear in contact with / $\mathrm{u}$ / (RECASENS: 2004). Recasens and Espinosa's (2005) study provides F2 frequency values for clear and dark laterals in several languages considering word position and vowel context. Table 1 has been adapted from Recasens and Espinosa (2005) to provide the data from F2 frequency values of Spanish clear laterals and American English and Eastern Catalan dark laterals realization. As we can observe 
below, higher F2 ranges are found in Spanish clear /1/ and lower ranges in Eastern Catalan dark $/ \uparrow /$ and American English.

\begin{tabular}{|c|c|c|c|}
\hline Language Context & /i/ & $\mid a /$ & $/ \mathbf{u} /$ \\
\hline \multicolumn{4}{|l|}{ Clear /1/ } \\
\hline \multirow[t]{3}{*}{ Spanish } & 1800 & 1560 & 1400 \\
\hline & $1630-2195$ & $1216-1500$ & $1300-1420$ \\
\hline & 1960 & 1520 & 1410 \\
\hline \multicolumn{4}{|l|}{ Dark / // } \\
\hline Easter (\#_) & 1250 & 1000 & 1050 \\
\hline \multirow[t]{2}{*}{ Catalan } & $1349-1450$ & $1065-1150$ & 1000 \\
\hline & 1000 & 1000 & 850 \\
\hline American (\#_) & 1185 & 900 & 1070 \\
\hline \multirow[t]{2}{*}{ English } & 1170 & 1000 & 1000 \\
\hline & 740 & 870 & 655 \\
\hline
\end{tabular}

Table 1. F2 frequency values for $/ t /$ and $/ 1 /$. Data are given for word context in three different vowel contexts /i, a, u/

Another characteristic that differentiates these segments is the point and strength of contact in the apico-alveolar region. Dark laterals seem to have a more fronted dental-alveolar contact while light laterals are less fronted. Electropalatographic data suggests that the alveolar closure for $/ t /$ in American English (New York) is more anterior and less variable than in other languages. In Eastern Catalan it is articulated with less dorsopalatal contact and more closure fronting in syllable final position than in syllable initial position. There is a consensus between alveolarity and clarity in laterals and dentality and darkness and this is also found in other coronal segments (RECASENS and ESPINOSA: 2005). In the present study, we specifically examine acoustic data.

\section{CROSS-LINGUISTIC TRANSFERENCE}

Researchers have long attempted to explain the phenomena of language transfer. In spite of previous models and research that assumed the L1 as the only source of transfer, such as the First Language Transfer Hypothesis (GARCIA LECUMBERRY \& GALLARDO: 2005, PYUN: 2005), current research has falsified that assumption. The Cumulative En- 
hanced Model (CEM) (FLYNN et al.: 2004) provided evidence that the L1 is not the only source of transference. They examined the production of restrictive relative clauses in L1 Kazakh/L2 Russian/L3 English speakers and demonstrated that the L2 can also influence in the development of complementizer phrase (CP) structures. Therefore, they suggested that linguistic knowledge of previously acquired languages can help in the acquisition of a subsequent language or remain neutral. Also, in L3 phonology, Gut's (2010) findings supported the CEM that discards the L1 as the main source of transfer. In his experiment he tested vowel reduction and speech rhythm in 4 trilinguals. Results showed that there was no clear evidence that the phonological properties of the L1 influenced vowel reduction and speech rhythm. On the other hand, the 'L2 Status Factor' account maintains that the L2 is more prone to be transferred than the L1 since the L2 blocks the access to the L1. Rothman and Cabrelli Amaro's (2010) tested the Null-Subject Parameter in L1 English/ L2 Spanish learning Italian or French as their L3 and results were compatible with the 'L2 Status Factor' since they found only transference from participants' L2. Later research tested pre/post nominal adjective in the DP in twelve L1 Italian/L2 English speakers learning Spanish as their L3 and fifteen L1 English/L2 Spanish speakers learning Portuguese as their L3 (ROTHMAN: 2010). Results supported CEM because transfer into the L3 occured from previously acquired languages. Findings also invalidated the 'L2 Factor Status' model since L1 Italian/L2 English/ L3 Spanish group were transferring from their L1. In view of these results, Rothman (2010) suggested that proximity, or as proposed by Kellerman (1983) psycho-typological proximity, of the L3 with previously acquired languages can be a deterministic variable to predict which of these previous systems is selected for transference in adult acquisition. He proposed a modification of CEM model and put forward the Typological Primacy Model (TPM) (ROTHMAN: 2010). Other research of morphosyntax (MONTRUL, DIAS \& SANTOS: 2011) or in the domain of the lexicon (CENOZ: 2005; FOUSER: 2001; RINGBOM: 1987, 2007; VOGEL: 1992) has also shown that transfer is selective and typology of the language is deterministic. 
As mentioned before, there are few studies that test phonological transfer in L3 acquisition. Among them, Gut's (2010) study that tested vowel reduction and rhythm in 4 trilingual speakers (mentioned above). Participants in Gut's study had varied native languages or L1s (Polish, Russian, Hungarian, and Spanish). Also, proficiency and attainment in the L2 differed across participants. One of the participants began learning English at twelve-year-old, but never lived in an English-speaking country and used only occasionally his/her L2. The other three participants acquired English around the same age and were exposed to the language in an English-speaking country and also used it on a regular basis at work at the time of the recording. Also, participant ages ranged from 30 to 50 which might have added an effect on the task performance. Another study on L3 phonology (CABRELLI AMARO \& ROTHMAN: 2010) only focused on regressive transfer, that is, phonological features of the L3 are transfered to the previously acquired language. In this case study they focused on one sequential and one simultaneous English/Spanish speaker who were learning Brazilian Portuguese as their L3. Results showed that an L2 acquired post puberty is prone to phonological influenced when acquiring an L3.

The present study investigates patterns of progressive transfer, in other words, how previously acquired languages influence the phonology of the L3. This study examines four early bilinguals (EB) Spanish/English learning Catalan as their L3, a language combination that has not been tested before. Previous studies in phonological transfer have tested L3 Brazilian Portuguese (Rothman \& CABRElli AMARO: 2011) or in the area of L3 morpho-syntax, L3 French and L3 Italian. Moreover, participants in previous studies were sequential bilinguals learning an additive language. The present research tests 4 early bilinguals. The phonological feature under investigation is the realization of laterals in Catalan. These segments have been investigated in bilingual acquisition (SIMONET: 2010), but the present research will be innovative in providing early bilinguals' transference patterns in L3 acquisition. The main goal of the study is to investigate the following research questions: 
- Is there phonological transfer from previously acquired languages?

- What are (if there is any transference) the patterns of transfer and phonetic realization of Catalan $/ \uparrow /$ ?

- How does phonetic environment relate to L3 phonological transfer (if any)?

- Does bilingual proficiency in the L3 correlate with phonological transfer (if any)?

As we have mentioned, none of the models of L3 language acquisition has any predictions for phonological transference. According to the CEM we will expect a facilitative transfer from one of the previous acquired languages. In this case, English dark /1/, at least in the syllable position where takes place in English (syllable coda position), will facilitate the pronunciation of Catalan $/ \uparrow /$. However, considering language proximity between Catalan and Spanish the TPM will predict transfer of Spanish only lateral, clear /1/, despite the fact that English dark $/ t /$ would be the more economical source of transfer.

There are no specific predictions about bilinguals' phonological proficiency in the L3 and transfer or target-like performance; however, studies of L2 acquisition have posed that student' gradual exposure and proficiency in the L2 correlates with more target-like production (FACE \& MENKE: 2009). Thus, we will expect more target like performance for those bilinguals with higher proficiency in Catalan.

\section{METHOD}

\subsection{PARTICIPANTS}

Four participants Spanish/English early bilinguals (EB) learning Catalan as their L3 participated in the study. Participants were asked to complete a language background questionnaire and self-report proficiency test where they provided information about language use and proficiency (LEAP-Q, MARIAN, BLUMENFELD \& KAUSHANSKAYA: 2007). Two of the EBs were born in the States and two of them were born in Latin American countries and arrived to the United States by the age 3 and 7 years old. All EBs were exposed to Spanish since childhood. Three out of the four EBs rated their Spanish proficiency 7-8 out 
of 10 and one reported 10 out of 10 being able to function in the language like a native speaker. Three out of four of the EBs reported English as their dominant language and the other EB reported to be professionally and academically dominant in English and, informally and in the environment of the family, dominant in Spanish.

Participants were recruited from the University of Florida. All participants took 3/4 semesters of Catalan and were actively participating in Catalan cultural activities such as movie nights and theater shows. Thus, subjects in this study were highly motivated Catalan learners and intensively receiving exposure of Catalan language. Students with 3 semesters of Catalan formal instruction and exposure were considered beginner level and student with 4 semesters of Catalan formal instruction and exposure were considered intermediate level. Results in the selfreport proficiency questionnaire confirmed participants' proficiency level (LEAP-Q, MARIAN, BLUMENFELD \& KAUSHANSKAYA: 2007).

The present study required native or higher proficiency in their L1s or L1/L2. Therefore, a measure to assess bilinguals' phonological proficiency/fluency was administered. Participants were recorded narrating a brief children's story (The Three Little Pigs) in Spanish and English. Six native speakers rated participants' recordings from 1 to 4 (1 being non-native accent and 4 being native accent). This was administered as a mean of assessing participants' fluency in their L1s or L1/L2. Judges' ratings confirmed that early bilinguals had native-like oral proficiency in their languages. Also, a Pronunciation Attitude Inventory Questionnaire (ELLIOT: 1995) was administered to find out subjects' attitudes towards pronunciation when acquiring a foreign language.

\subsection{INSTRUMENT AND PROCEDURE}

Participants were recorded carrying out a picture elicitation task administered in Catalan. Participants were told to name the picture appearing on the screen. Researcher provided a prompt such as Aqui es pot veure... (here you can see...) and participants were instructed to use the definite article el, la, l', els, les to name the picture on the screen. When describing a phsyical state, emotion etc, such as malalt (sick), researcher use the prompt Com se sent la persona? (how does the person 
feel?) Tokens were controlled for vowel context (front and back vowels) and position in the utterance (absolute coda, syllable coda, absolute onset and syllable onset). A total of 36 Catalan words and 36 fillers distributed randomly throughout the task were used. Catalan tokens were selected from the vocabulary use in their Catalan textbook to ensure participants will recognize the pictures. Catalan tokens excluded cognates, but due to the limited vocabulary in Catalan some near-cognates were included (see table with materials).

\begin{tabular}{|c|c|c|c|c|c|c|}
\hline & Tokens & Translation & Anterior & Tokens & Translation & Posterior \\
\hline $\begin{array}{c}\text { Absolute } \\
\text { Onset }\end{array}$ & $\begin{array}{l}\text { l'avió } \\
\text { l'escola } \\
\text { l'estiu } \\
\text { l'anell }\end{array}$ & $\begin{array}{l}\text { aircraft } \\
\text { school } \\
\text { summer } \\
\text { ring }\end{array}$ & $\begin{array}{l}\# \text { la- } \\
\text { \#le- }\end{array}$ & $\begin{array}{l}\text { l'oli } \\
\text { l'ós } \\
\text { l'ou } \\
\text { l'u }\end{array}$ & $\begin{array}{c}\text { Oil } \\
\text { bear } \\
\text { egg } \\
\text { one }\end{array}$ & $\begin{array}{l}\text { \#lo- } \\
\text { \#lu- }\end{array}$ \\
\hline $\begin{array}{c}\text { Syllable } \\
\text { Onset }\end{array}$ & $\begin{array}{l}\text { gelat } \\
\text { escola } \\
\text { televisió } \\
\text { malalt }\end{array}$ & $\begin{array}{l}\text { ice-cream } \\
\text { school } \\
\text { television } \\
\text { sick }\end{array}$ & $\begin{array}{l}\text { la- } \\
\text { le- }\end{array}$ & $\begin{array}{c}\text { Meló } \\
\text { calor } \\
\text { pantalons } \\
\text { malhumorat }\end{array}$ & $\begin{array}{c}\text { melon } \\
\text { hot } \\
\text { pants } \\
\text { bad-humored }\end{array}$ & $\begin{array}{l}\text { lo- } \\
\text { lu- }\end{array}$ \\
\hline $\begin{array}{l}\text { Absolute } \\
\text { Coda }\end{array}$ & $\begin{array}{l}\text { regal } \\
\text { pèl } \\
\text { mel } \\
\text { cel }\end{array}$ & $\begin{array}{l}\text { present } \\
\text { hair } \\
\text { honey } \\
\text { sky }\end{array}$ & $\begin{array}{l}-\mathrm{al} \# \\
-\mathrm{el} \#\end{array}$ & $\begin{array}{l}\text { llençol } \\
\text { juliol } \\
\text { núvol } \\
\text { pèsol }\end{array}$ & $\begin{array}{l}\text { linen } \\
\text { july } \\
\text { cloud } \\
\text { pea }\end{array}$ & -ol\# \\
\hline $\begin{array}{c}\text { Syllable } \\
\text { Coda }\end{array}$ & $\begin{array}{l}\text { malalt } \\
\text { alt } \\
\text { alberginia } \\
\text { pèl-roig }\end{array}$ & $\begin{array}{c}\text { sick } \\
\text { tall } \\
\text { eggplant } \\
\text { red-hair }\end{array}$ & $\begin{array}{l}-\mathrm{al} \\
-\mathrm{el}\end{array}$ & $\begin{array}{c}\text { Dolç } \\
\text { colze } \\
\text { escoltar } \\
\text { pulmons }\end{array}$ & $\begin{array}{l}\text { sweet } \\
\text { elbow } \\
\text { listen } \\
\text { lungs }\end{array}$ & $\begin{array}{l}-\mathrm{ol} \\
-\mathrm{ul}\end{array}$ \\
\hline
\end{tabular}

Table 2. Catalan tokens. Tokens selected for syllable position and vowel context.

Participants were recorded in a laboratory setting in one session. First participants completed the language background questionnaire and self-report proficiency test (LEAP-Q. MARIAN, BLUMENFELD \& KAUSHANSKAYA: 2007) and were recorded in the picture elicitation task in Catalan and the short story telling (The Three Little Pigs) in Spanish and English. After the picture elicitation task participants completed the Pronunciation Attitude Inventory Questionnaire (ELLIOT: 1995). The investigator addressed participants in the language of the task. Data was collected using a solid-state digital recorded (Marantz PMD660) through a head-mounted microphone and then trans- 


\section{Revista de Filologia}

ferred to a computer to be acoustically analyzed via Praat software (BOERSMA \& WEENINK: 2009)

\section{ACOUSTIC ANALYSIS}

The acoustic analysis was carried out by analyzing F2 formant values. These values are an optimal acoustic correlate of degree of darkness in alveolar lateral (RECASENS \& ESPINOSA: 2005). Participants' production of $/ \mathrm{t} /$ in L3 Catalan were compared to the native values of $/ \mathrm{t} /$ provided in Recasens and Espinosa's (2005). Recasens \& Espinosa (2005) provided acoustic data of laterals with specific vowel contexts (a, $\mathrm{i}, \mathrm{u}$ ) and in certain syllable positions (word onset \# _ intervocalic $\mathrm{V}_{-} \mathrm{V}$ and final onset _\#). In this study Recasens and Espinosa's (2005) F2 values of $/ \mathrm{a} /$ were an index for tokens in our data that appear in contexts with anterior vowels $(e, a)$ and $F 2$ values of $/ u$ / for tokens in contexts with posterior vowels $(\mathrm{o}, \mathrm{u})$. Also, the $\mathrm{F} 2$ values of the intervocalic syllable position (V_V) in Recasens \& Espinosa (2005) was an index for syllable initial tokens in our data since they only provided specific data of the dark lateral realization in absolute onset, absolute coda and intervocalic position. Table 3 (column 3 and 4) shows the formant values taken as standpoint to compare our data. 


\begin{tabular}{|c|c|c|c|}
\hline $\begin{array}{c}\text { Recasens \& } \\
\text { Espinosa }(2005)\end{array}$ & $\begin{array}{c}\text { Tokens } \\
\text { Syll. Context }\end{array}$ & $\begin{array}{l}(1) \text { dark } \\
\text { realization }\end{array}$ & $\begin{array}{l}(2) \text { clear } \\
\text { realization }\end{array}$ \\
\hline \#_ & $\begin{array}{l}\text { \#la- } \\
\text { \#le- }\end{array}$ & F2 Hz 1000 & $\mathrm{~F} 2 \mathrm{~Hz} 1560$ \\
\hline V_V & $\begin{array}{l}\text { la- } \\
\text { le- }\end{array}$ & F2 Hz 1150 & $\mathrm{~F} 2 \mathrm{~Hz} 1500$ \\
\hline${ }_{-} \#$ & $\begin{array}{l}- \text {-al\# } \\
\text {-el\# }\end{array}$ & F2 Hz 1000 & $\mathrm{~F} 2 \mathrm{~Hz} 1520$ \\
\hline$-\#$ & $\begin{array}{l}-\mathrm{al} \\
-\mathrm{el}\end{array}$ & F2 Hz 1000 & $\mathrm{~F} 2 \mathrm{~Hz} 1520$ \\
\hline \#_ & $\begin{array}{l}\text { \#lo- } \\
\text { \#lu- }\end{array}$ & F2 Hz 1050 & F2 Hz 1400 \\
\hline $\mathrm{V}_{-} \mathrm{V}$ & $\begin{array}{l}\text { lo- } \\
\text { lu- }\end{array}$ & $\mathrm{F} 2 \mathrm{~Hz} 100$ & $\mathrm{~F} 2 \mathrm{~Hz} 1420$ \\
\hline -\# & -ol\# & $\mathrm{F} 2 \mathrm{~Hz} 850$ & $\mathrm{~F} 2 \mathrm{~Hz} 1410$ \\
\hline${ }_{-} \#$ & $\begin{array}{l}-o l \\
-u l\end{array}$ & $\mathrm{~F} 2 \mathrm{~Hz} 850$ & $\mathrm{~F} 2 \mathrm{~Hz} 1410$ \\
\hline
\end{tabular}

Table 3. From Recasens \& Espinosa (2005). F2 values of clear and dark laterals in Spanish and Eastern Catalan. It represents laterals realization considering syllable and vowel context.

\section{RESULTS}

If we compare subject realization of laterals in L3 Catalan, Chart 1. shows that two out of the four participants favor the production of dark laterals. One of them produced almost all segments with F2 values resembling Catalan $/ \mathrm{t} /$. Two out of the four participants favored the production of clear $/ 1 /$ and one of them produced almost all lateral segments with F2 values similar to Spanish clear /1/. 


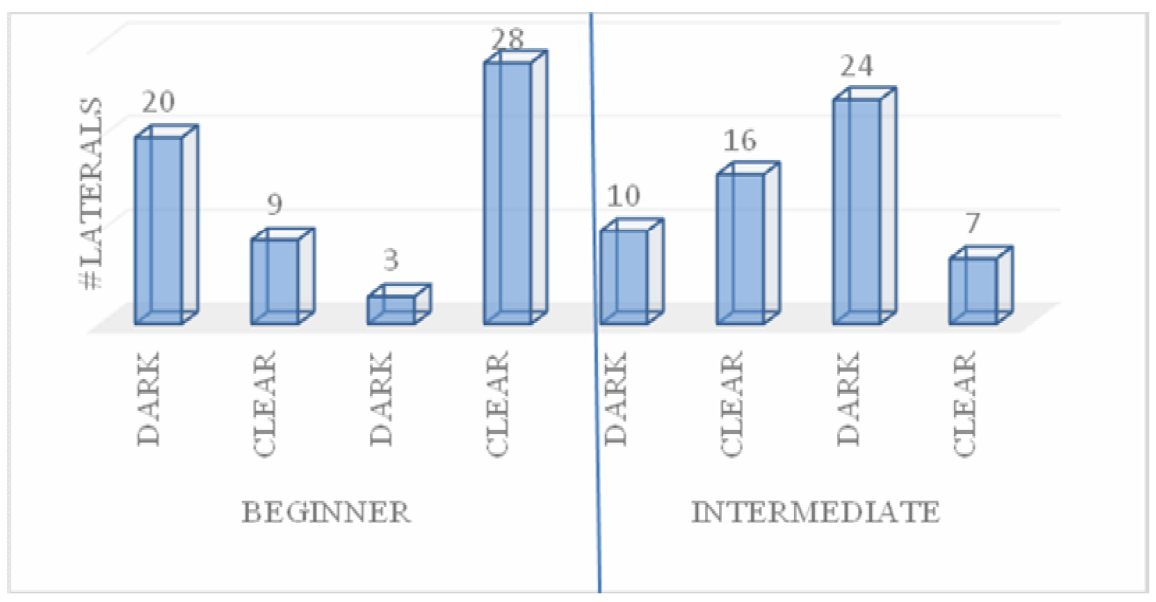

Chart 1. Participants' realization of laterals

The production of Catalan $/ \downarrow /$ was clearly disfavored in absolute onset or syllable onset. However, absolute coda or syllable coda triggered the production of laterals as dark segments. The participant who mainly produced laterals as clear /1/, 28 out of the 32 tokens, produced dark segments only in coda position.

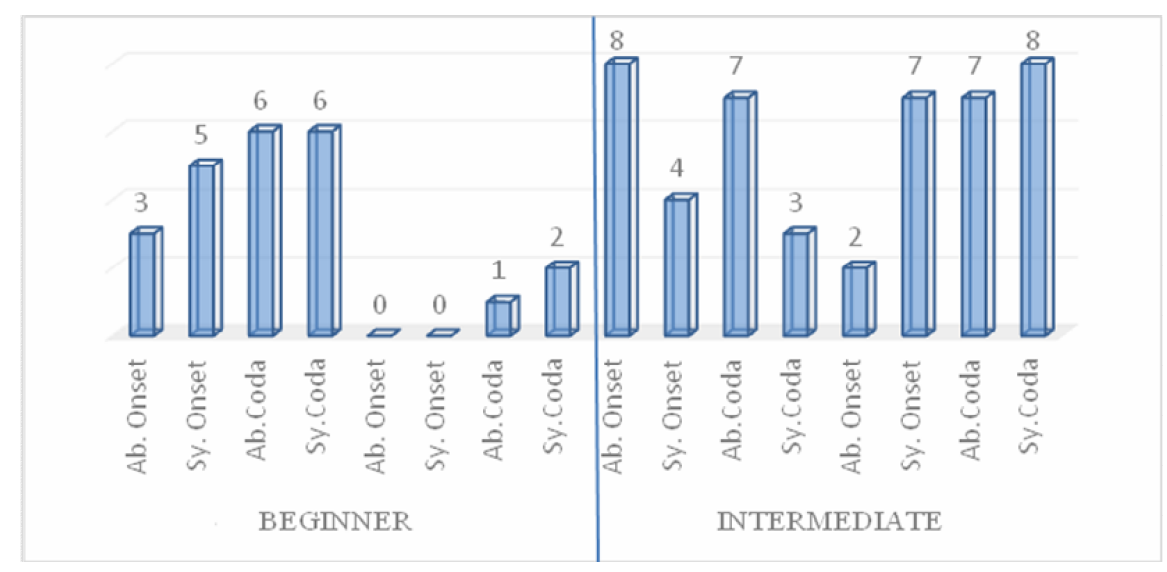

Chart 2. Dark $/ \uparrow /$ syllable position 
Chart 3. below shows that vowel context had an effect in the production of lateral segments. The production of $/ t /$ was mainly favored when the segment was in contact with back vowels $(/ \mathrm{o} /$ and $/ \mathrm{u} /$ in the data).

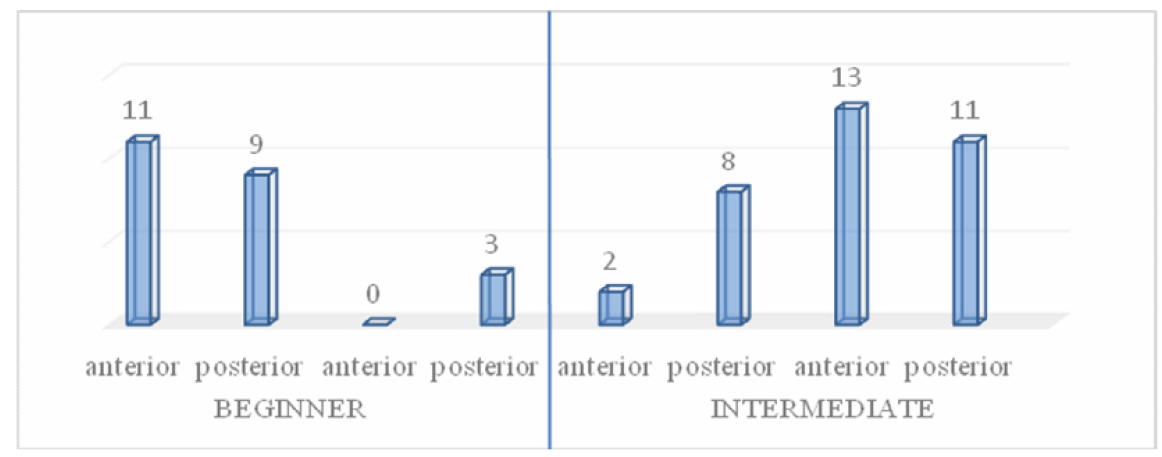

Chart 3. Dark / $t /$ realization: Vowel adjacency

As shown in chart 4. proficiency did not predict target-like realization of $/ \mathrm{t}$. One of the beginners produced more target-like dark segments than one of the intermediate learners.

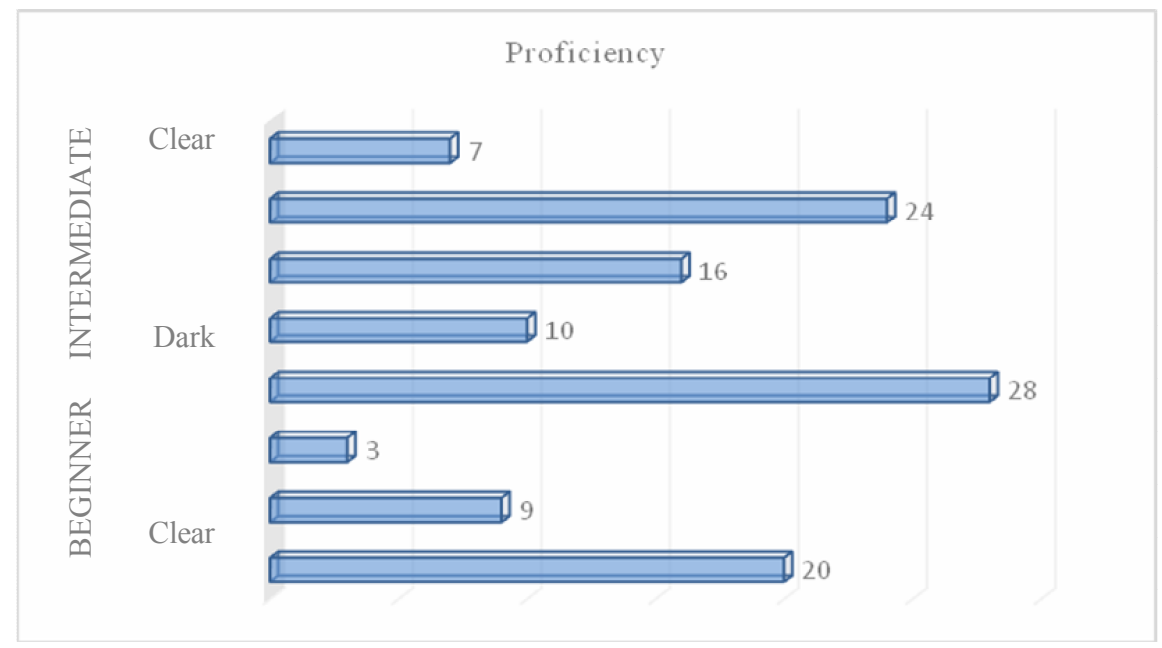

Chart 4. Proficiency and lateral realization 


\section{DISCUSSION AND CONCLUSION}

Findings in this study do not seem to support the TPM (ROTHMAN: 2010) that predicts that typological proximity with already acquired languages will be a deterministic factor of transference. Only one of the participants in our research mainly transferred phonological features of Spanish clear /1/ in the target production of Catalan dark laterals. Therefore, results in our study are better explained by the CEM (FLYNN et al.: 2004), that predicts that previously acquired languages can help in the acquisition of a subsequent language.

Unlike other models that suggest that the typological proximity of one of the bilingual' languages (in this case Catalan) might be the source of transference into the L3, participants produced phonological segments that aimed to a target-like production of dark $/ 1 /$ in Catalan. Since $/ t /$ is found in English (with slightly different F2 values, see table 1) the phonological repertoire of English might have aided the production of the dark lateral. However, participants might have transferred the phonological distribution of English $/ \mathrm{t}$ / (postvocalic, coda and absolute coda) since more dark segments were found in that syllable position in comparison with onset and absolute onset. However, tokens in absolute onset were selected to be produced with Catalan article [l'] and the vowel in word initial position (see Table 2) and participants sometimes hesitated in the production of these tokens. Thus, this could be indicative of participants' constraints when using the definite article since they are almost identical to the Spanish definite article.

Vowel quality such as front and backness also favored a darker segment. As it was expected, laterals that were preceded by back vowels, such as $o$ and $u$ in our data, favored the articulation of $/ t /$ since this segment is partly produced with the tongue touching the velum, that is, the back part of the mouth cavity. This effect was also found in Recasens $\&$ Espinosa (2005) with electropalatographic data. Therefore, this study provides more evidence on a darker realization of laterals with posterior vowels.

Proficiency in the L3 was not deterministic in predicting more or less transference or facilitatory effects from Spanish or English since one of the beginners (three semesters of Catalan formal instructions) pro- 
duced mainly target-like segments. However, it can be mentioned the highest production of clear / $1 /$ in all Catalan tokens was produced by the other beginner. Even though the self-report proficiency test determined two different levels, there is a small difference in exposure/formal instruction between the two groups. That could explain why proficiency did not predict target-like production.

The only instrument that predicted target-like pronunciation was the Pronunciation Attitude Inventory Questionnaire (ELLIOT: 1995). Participants who considered target-like pronunciation of the language important were the ones who produced more Catalan dark segments. The participant who produced more /l/ (Spanish-like) evaluated grammar fluency more important than pronunciation. A more in-depth analysis of the language attitude questionnaire could help understand a possible correlation between attitudes and phonological patterns observed.

It must be reiterated that neither the TPM, or the CEM, or any other previous model of L3 acquisition makes any prediction about phonological transfer. Thus, there is a need for research to better account for phonological transfer in L3 acquisition.

\section{REFERENCES}

BAYONA, P. (2009): «Crosslinguistic Influences in the Acquisition of Spanish L3», Ann Arbor, ProQuest. 70 (12), The University of Western Ontario (Canada), p. 46-54.

Boersma, P. \& D. WeENINK (2009): Praat: doing phonetics by computer (Version 5.1.04) [Computer program]. http://www.praat.org/

BARDEL C. and Y. Falk (2007): "The role of the second language in third language acquisition: The case of Germanic syntax Second Language Research 23, p. 459-484.

CABrelli Amaro, J. \& J. Rothman (2010): «On the L3 acquisition and phonological permeability: A new test case for debates on the mental representation of non-native phonological system», International Review of Applied Linguistics in Language Teaching, 48 (2/3), p. 275-296. 
Cabrelli Amaro, J. (2012): L3 Phonology: An Understudied Domain. In J. CABrelli Amaro, S. FlynN, \& J. Rothman (Eds.), Third Language Acquisition in Adulthood, Amsterdam, John Benjamins, p. 33-60

ECKE, P \& C. J. HALl (2000): «Lexicalilische Fehler in Deutch als Drittsprache. Translexikalischer Einfluss aud dre Ebenen der mentale Reprasentation», Deutch als Fremdsprache, 37, p. 30-36.

ELLIS, G. (1996): «How culturally appropriate is the communicative approach?», ELT journal, 50 (3), p. 213-218.

FLYNN S., C. FOLEY \& I. Vinnitskaya (2004): «The cumulativeenhanced model for language acquisition: Comparing adult's and children's parents of development in first, second and third language acquisition of relative clauses», The International Journal of Multilingualism, 1, p. 3-16.

Garcia LeCUMBerRI, M. \& F. Gallardo (2003): «English EFL sounds in school learners of different ages», in M. GARCIA MAYO \& GARCIA LeCUMBerri (ed.), Age and the Acquisition of English as a Foreign Language, Clevedon, Multilingual Matterns, p. 115135.

GUT, U. (2010): «Cross-linguistic influence in L3 phonological acquisition», International Journal of Multilingualism, 7 (1), p. 1938.

HuAlde, J. I. (2005): The sounds of Spanish, Cambridge, Cambridge University Press.

KellermaN, E. (1983): Now you see it, now you don't, in S. GASS \& L. SELINKER (ed.), Language transfer in language learning. Rowley, Newbury house, p. 112-134.

Marian, V., H. K. Blumenfeld \& M. Kaushanskaya (2007): «The Language Experience and Proficiency Questionnaire (LEAP-Q): Assessing language profiles in bilinguals and multilinguals», Journal of Speech, Language, and Hearing Research, 50 (4), p. 940-967.

Montrul, S., R. Dias \& H. SAntos (2011): «Clitics and object expression in the L3 acquisition of Brazilian Portuguese. 
Structural similarity matters for transfer. Special issue of Second Language Research on L3 Acquisition.

PYUN, K. (2005): «A model of interlanguage analysis. The case of Swedish by Korean speaker», in B. Hufesein and R. J. Fouser (ed.), Introductory Readings in L3, Tubingen, Stauffenburg Verlag, p. $55-70$

ReCASENS, D., J. Fontdevila \& M. D. PALlares (1995): «Velarization degree and coarticulatory resistance for $/ 1 /$ in catalan and german», Journal of Phonetics, 23 (1-2), p. 37-52.

RECASENS, D. \& A. ESPINOSA (2005): «Articulatory, positional and coarticulatory characteristics for clear / $/ /$ and dark / $/ /$ :Evidence from two Catalan dialects», Journal of the International Phonetic Association, 35, p. 1-25.

RECASENS, D. (2004): «Darkness in [1] as scalar phonetic property: Implications for phonology and articulatory control», Clinical Linguistics and Phonetics, 18, p. 593-603.

Rothman, J. \& J. CABrelli Amaro (2010): «What variables condition syntactic transfer?: a look at the L3 initial state», Second language Research 26, 2, p. 189-218.

RothmAN, J. (2010): «L3 Syntactic transfer selectivity and typological determinacy: The typological primacy Model», Second Language Research 27 (1), 107-127.

SOLÀ, J. \& G. Rigau i Oliver (2002): Gramàtica del català contemporani, Barcelona, Empúries. 